\title{
Pelatihan Penggunaan Aplikasi untuk Memproduksi Bahan Ajar bagi Guru SMP Budya Wacana Yogyakarta
}

\author{
Yudi Perbawaningsih ${ }^{\# 1}$, R.A. Vita Astuti ${ }^{* 2}$, Brahma Putra Pratama ${ }^{\# 3}$ \\ \#Departemen Ilmu Komunikasi, Universitas Atma Jaya Yogyakarta \\ Jl. Babarsari No. 6 Yogyakarta 55281 \\ ${ }^{1}$ yudi.perbawaningsih@uajy.ac.id \\ 33rahma.pratama@uajy.ac.id \\ *Departemen Ilmu Komunikasi, Universitas Atma Jaya Yogyakarta \\ Jl. Babarsari No. 6 Yogyakarta 55281 \\ ${ }^{2}$ ra.vita@uajy.ac.id
}

\begin{abstract}
Abstrak-Pandemi Covid-19 menyebabkan adanya pembatasan interaksi langsung tatap muka pada pembelajaran sehingga proses belajar mengajar dilakukan secara daring. Hal ini menuntut guru dan murid memiliki kemampuan memanfaatkan teknologi informasi dan komunikasi. Beberapa studi menunjukkan bahwa terdapat banyak hambatan yang masih menjadi tantangan, terutama pada guru. Hambatan mendasar adalah kurangnya kecakapan guru dalam memanfaatkan teknologi informasi dan komunikasi atau teknologi digital dalam pengajaran daring, terutama dalam memproduksi materi pelajaran. Hambatan ini juga dialami oleh guru-guru SMP Budya Wacana Yogyakarta. Guru-guru ini memanfaatkan media digital sebatas pada memberikan kuliah secara sinkron secara sederhana, padahal kualitas sinyal operator selular dan stabilitas jaringan belum tentu dimiliki oleh guru dan siswa. Kegiatan pengabdian ditujukan untuk meningkatkan pengetahuan, pemahaman dan keterampilan teknis pemanfaatan beragam aplikasi digital untuk pembuatan materi pengajaran dan presentasi. Pelatihan dilakukan dalam tujuh pertemuan dan mencakup dua sesi utama: (1) penggunaan aplikasi (PowerPoint recording, Screencast-OMatic, dan Anchor) dan (2) berbicara di depan kamera/perekam. Hasil dari pelatihan ini adalah produk bahan ajar para guru SMP berupa video, audio dan visual, serta modul penggunaan aplikasi.
\end{abstract}

Kata kunci-aplikasi, kecakapan komunikasi digital, pembelajaran daring, teknologi informasi dan komunikasi

Abstract-The Covid-19 pandemic has led to restrictions of face-to-face classes so that the teaching and learning process is carried out via online. It requires teachers and students to have the ability to utilize information and communication technology. Some studies have shown that there are lots of challenges in the learning process, especially for the teachers.
The fundamental obstacle is their lack of competence in utilizing digital technology in online teaching, especially in producing teaching materials. This problem is also experienced by the teachers of Budya Wacana Yogyakarta Junior High School. They are forced to employ digital teaching media in simple synchronous way, even though the signal quality of cellular operators and networks stability may not be owned by teachers and students. The activity of the community service training aims to increase knowledge, understanding, and technical skills in the use of various digital applications for creating teaching and presentation materials. The training was conducted in seven meetings and covered in two main sessions: (1) usage of applications (PowerPoint recording, Screencast-OMatic, and Anchor) and (2) speaking in front of the camera/recorder. The result of this training is the product of teaching materials of the teachers in the form of video, audio and visual, as well as a module of the application usage.

Keywords: application, digital communication competence, information and communication technology, online learning

\section{PENDAHULUAN}

Awal Maret 2020, virus corona (Covid-19) mulai menyebar di beberapa daerah di Indonesia. Dimulai pada tanggal 6 Maret 2020 [1], terdapat dua kasus positif yang ditemukan dan terus terjadi peningkatan kasus harian hingga mencapai jumlah ratusan pada tanggal 24 Maret 2020. Penyebaran virus ini memengaruhi berbagai aspek kehidupan masyarakat Indonesia, termasuk dalam bidang pendidikan. Kejadian ini mendorong Menteri Pendidikan dan Kebudayaan RI, Nadiem Anwar Nakarim, menerbitkan Surat Edaran No. 4 Tahun 2020 tentang Pelaksanaan Kebijakan Pendidikan Dalam Masa Darurat Penyebaran Coronavirus Disease (Covid-19) [2]. Berdasarkan surat 
edaran menteri tersebut, proses pembelajaran dilakukan dari rumah atau pembelajaran daring/jarak jauh dengan memanfaatkan jaringan internet. Kebijakan ini tidak hanya membuat para siswa belajar dari rumah, tetapi juga mendorong para guru untuk menggunakan teknologi komunikasi dan informasi dalam melaksanakan kegiatan pembelajaran. Sebenarnya, ada pandemic atau tidak, di era digital ini kecakapan komunikasi digital sangat penting bagi guru. Di sisi lain, di banyak negara guru-guru ternyata memiliki kecakapan digital yang masih rendah [3], [4].

Beberapa studi menunjukkan bahwa terdapat banyak hambatan yang masih menjadi tantangan, terutama pada guru. Penelitian Nurgiansah dan Sukmawati [5] menyampaikan bahwa faktor usia bisa menyebabkan keengganan belajar teknologi dan tuntutan metode pembelajaran yang menarik dan tidak membosankan siswa menjadi tantangan yang cukup besar. Hasil penelitian Sari [6] menambahkan bahwa pembelajaran daring ini menuntut kreativitas dan inovasi dari para pendidik. Hambatan mendasar adalah kurangnya kecakapan guru dalam memanfaatkan teknologi informasi dan komunikasi atau teknologi digital dalam pengajaran daring, terutama dalam memproduksi materi pelajaran.

Rendahnya kecakapan digital para guru diakibatkan oleh (1) Tidak ada integrasi teknologi digital sebagai alat pedagogi dengan seluruh mata pelajaran [7] dan (2) sikap penolakan pada teknologi karena echnophobia dan skepticism [8]. Tentang skepticism, Perbawaningsih [9] juga menyebutkan bahwa salah satu faktor yang mempengaruhi rendahnya kecakapan digital adalah sikap mental dari komunitas akademik dan pimpinan yang tidak mendukung pemanfaatan ICT.

Di Indonesia, ada dua hambatan utama pembelajaran daring: (1) kualitas guru, yaitu terkait kemampuan menggunakan teknologi informasi dan komunikasi yang sangat rendah; dan (2) sarana prasarana, yaitu meliputi jaringan internet yang belum menjangkau daerah pedesaan, jaringan internet yang tidak stabil, dan biaya untuk membeli kuota internet [10], [11].

Hambatan ini juga dialami di sekolah-sekolah di Yogyakarta, walaupun secara lokasi di kota besar dan fasilitas internet cukup memadai. Salah satunya di SMP Budya Wacana Yogyakarta. SMP ini merupakan salah satu sekolah yang ada di bawah naungan Yayasan Pendidikan dan Pengajaran Nasional (YPPN) Budya Wacana yang didirikan pada tahun 1959 [12]. Berdasarkan wawancara dengan Ketua Pengurus YPPN (27 Agustus 2019), beberapa sekolah yang beralifiliasi agama Kristiani, termasuk SMP Budya Wacana, mengalami keadaan yang sulit dengan adanya kebijakan pemerintah terkait zonasi dan kompetisi dengan sekolah swasta lainnya sehingga positioning sekolah perlu ditinjau kembali. Positioning kemudian diimplementasikan dengan melakukan pergantian kurikulum yang sesuai dengan kebutuhan di era industri 4.0 dan meningkatkan kapabilitas para guru dalam menggunakan teknologi informasi dan komunikasi.
Pada program pengabdian sebelumnya, pelatihan pengembangan kecakapan komunikasi digital telah dilakukan kepada guru dan siswa SMP Budya Wacana Yogyakarta. Tujuan pelatihan ini adalah untuk menentukan positioning SMP Budya Wacana Yogyakarta melalui pembaruan kurikulum mata pelajaran dan untuk meningkatkan kapabilitas para guru dan siswa terkait literasi komunikasi digital. Program ini terdiri dari tiga tahap: (1) merencanakan, membuat, dan mengembangkan materi kecapakan komunikasi digital melalui rancangan pembelajaran semester (RPS), (2) implementasi RPS dalam aktivitas belajar mengajar di kelas dengan menggunakan modul dan model pembelajaran yang dihasilkan dari tahap 1, dan (3) evaluasi modul dan model pembelajaran yang telah diimplementasikan bersama dengan para guru pada tahap 2. Keluaran dari program ini adalah RPS, modul dan model pengembangan pembelajaran, serta produk digital dari para siswa.

Program pelatihan penggunaan aplikasi untuk memproduksi bahan ajar bagi guru SMP Budya Wacana Yogyakarta merupakan program lanjutan dari program pelatihan pengembangan kecakapan komunikasi digital bagi guru dan siswa SMP Budya Wacana Yogyakarta. Jika program pelatihan sebelumnya menekankan pada kurikulum dan materi pembelajaran komunikasi digital, program pelatihan ini lebih berfokus pada cara penyampaian materi dari guru kepada siswa dalam pembelajaran daring dan penggunaan teknologi informasi dan komunikasi berupa aplikasi untuk memproduksi bahan ajar sehingga dapat mendukung pembelajaran daring secara asikron.

Program pengabdian kepada masyarakat ini diadakan berdasarkan kebutuhan yang mendesak dan penting dari SMP Budya Wacana Yogyakarta dalam pengembangan kecapakan komunikasi digital bagi para guru. Pandemi Covid-19 mendorong para guru untuk tetap memberikan layanan pendidikan yang berkualitas meskipun pembelajaran harus dilaksanakan secara daring. Oleh karena itu, tujuan dari pelatihan ini adalah untuk meningkatkan pengetahuan, pemahaman dan keterampilan teknis pemanfaatan beragam aplikasi digital untuk pembuatan materi pengajaran dan presentasi sehingga para guru memiliki alternatif model pembelajaran jika ada kendala dalam melakukan pembelajaran daring secara sinkron.

\section{A. Masalah}

Pandemi Covid-19 menuntut diadakannya proses pembelajaran yang diadakan secara daring dari rumah sehingga tidak dimungkinkan adanya pertemuan tatap muka secara langsung (fisik) di kelas antara guru dan siswa. Kebijakan Menteri Pendidikan dan Kebudayaan RI terkait pembelajaran daring dalam masa pandemi Covid-19 membuat para guru SMP Budya Wacana merasa perlu mengembangkan kecakapan komunikasi digital dan mencari alternatif metode pembelajaran daring sehingga 
bisa mengatasi kendala-kendala yang muncul dari sisi kecakapan teknologi komunikasi dan penciptaan media belajar yang menarik.

Berdasarkan wawancara kepada para guru SMP Budya Wacana, sebagian besar merasa tidak memiliki kemampuan atau keterampilan yang cukup optimal dalam menggunakan teknologi informasi dan komunikasi yang ada untuk melakukan pembelajaran daring. Dalam proses pembelajaran sudah berjalan, para guru memanfaatkan media digital, seperti Zoom dan Google Meet, dan sebatas pada memberikan kuliah secara sinkron secara sederhana padahal kualitas sinyal operator selular dan stabilitas jaringan belum tentu dimiliki oleh para guru dan siswa. Selain itu, proses pembelajaran yang hanya dilakukan menggunakan aplikasi video conference tersebut secara sinkron dirasa kurang kreatif dan akomodatif sehingga membuat para siswa kurang memiliki semangat belajar, menunjukkan keaktifan yang rendah, dan mendapatkan hasil akhir yang tidak memuaskan. Oleh karena itu, pengembangan kecakapan komunikasi digital para guru dan optimalisasi penggunaan teknologi informasi dan komunikasi dapat membuat proses belajar dari rumah menjadi efektif. Selain itu, visi SMP Budya Wacana Yogyakarta untuk menjadikan para siswa dan gurunya memiliki kecakapan digital di era industri 4.0 dapat terwujud.

\section{METODE PELAKSANAAN}

Program pengabdian kepada masyarakat ini diadakan dalam bentuk pelatihan penggunaan aplikasi untuk memproduksi bahan ajar bagi guru SMP Budya Wacana Yogyakarta. Pelatihan dilakukan dalam tujuh kali pertemuan dan terdiri dari dua sesi utama: (1) penggunaan aplikasi (PowerPoint recording, Screencast-O-Matic, dan Anchor) dan (2) berbicara di depan kamera/perekam. Dalam pelatihan sesi pertama, para guru dikenalkan aplikasi PowerPoint recording, Screencast-O-Matic, dan Anchor dan mencoba mempraktikkan penggunaan fitur-fitur sampai menghasilkan keluarannya sehingga mereka lebih percaya diri dan dapat mengoperasikannya dengan optimal. Setelah itu di sesi kedua, para guru praktik berbicara di depan kamera/perekam yang disertai dengan contoh aktualnya. Setiap topik pelatihan dibawakan oleh tutor yang berbeda sesuai dengan keahlian dan jadwal yang telah disusun

Model pengembangan kecakapan komunikasi digital dapat diurakan dalam rencana pelatihan yang diselenggarakan di ruang laboratorium komputer SMP Budya Wacana Yogyakarta dalam tujuh kali pertemuan tatap muka langsung (offline), seperti pada tabel 1. Pada pertemuan pertama, guru diberi wawasan umum dan perkembangan terakhir tentang teknologi pendidikan berbasis internet. Selain itu, dari berbagai macam media pembelajaran digital yang dikenalkan, para guru diberi kesempatan untuk memilih beberapa media pembelajaran yang ingin difokuskan dalam pelatihan. Media pembelajaran digital yang dipilih dalam pelatihan ini mempertimbangkan sarana dan prasarana yang mudah diakses atau digunakan oleh para siswa dan guru.

TABEL 1

MODEL PENGEMBANGAN KECAKAPAN KOMUNIKASI DIGITAL

\begin{tabular}{|c|c|c|c|c|}
\hline Pertemuan & \begin{tabular}{|l|} 
Durasi \\
Waktu
\end{tabular} & Materi & Metode Belajar & Capaian \\
\hline 1 & 3 jam & $\begin{array}{l}\text { - Perkembangan Teknologi Komunikasi dan } \\
\text { Informasi dalam pendididikan } \\
\text { - Pengenalan umum beragam aplikasi untuk } \\
\text { produksi audio visual dan hasil/output pada } \\
\text { setiap aplikasi }\end{array}$ & $\begin{array}{l}\text { Penjelasan tutor, } \\
\text { dan diskusi }\end{array}$ & $\begin{array}{l}\text { Guru memahami perangkat-perangkat } \\
\text { TIK dan aplikasi pembelajaran }\end{array}$ \\
\hline 2 & $3 \mathrm{jam}$ & $\begin{array}{l}\text { - Mempersiapkan perangkat untuk } \\
\text { siap digunakan untuk produksi } \\
\text { audiovisual } \\
\text { - Unduh beragam aplikasi dan } \\
\text { membuat semua akun pribadi. }\end{array}$ & $\begin{array}{l}\text { Penjelasan tutor, } \\
\text { Praktik materi }\end{array}$ & 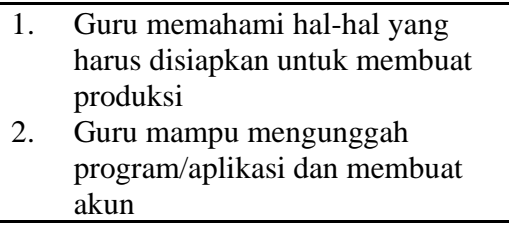 \\
\hline 3 & 3 jam & $\begin{array}{l}\text { - Membuat presentasi yang } \\
\text { menarik/konten yang baik (PowerPoint } \\
\text { recording, Video) } \\
\text { - Berbicara yang baik di depan } \\
\text { kamera/audio }\end{array}$ & $\begin{array}{l}\text { Penjelasan tutor, } \\
\text { Praktik materi }\end{array}$ & $\begin{array}{l}\text { 1. Guru mampu membuat atau } \\
\text { Menyusun naskah/konten/materi } \\
\text { pelajaran yang menarik } \\
\text { 2. Guru mampu berbicara dengan } \\
\text { baik di depan mic dan kamera }\end{array}$ \\
\hline 4 & 3 jam & - Berlatih Screencast-O-Matic (1) & $\begin{array}{l}\text { Penjelasan tutor, } \\
\text { Praktik materi }\end{array}$ & $\begin{array}{l}\text { 1. Guru mampu menggunakan } \\
\text { Screencast-O-Matic }\end{array}$ \\
\hline 5 & 3 jam & - Berlatih Screencast-O-Matic (2) & $\begin{array}{l}\text { Penjelasan tutor, } \\
\text { Praktik materi }\end{array}$ & $\begin{array}{ll}\text { 2. } & \text { Guru mampu mengedit dan } \\
& \text { mengintegrasikan dengan aplikasi } \\
& \text { lain. } \\
\end{array}$ \\
\hline
\end{tabular}




\begin{tabular}{|c|c|c|c|c|}
\hline 6 & 3 jam & - Berlatih PowerPoint recording & $\begin{array}{l}\text { Penjelasan tutor, } \\
\text { Praktik materi }\end{array}$ & $\begin{array}{l}\text { Guru mampu menggunakan } \\
\text { PowerPoint recording. }\end{array}$ \\
\hline 7 & 3 jam & $\begin{array}{l}\text { - Membuat rekaman audio dengan Anchor FM } \\
\text { - Evaluasi hasil produksi }\end{array}$ & $\begin{array}{l}\text { Penjelasan tutor, } \\
\text { praktik }\end{array}$ & 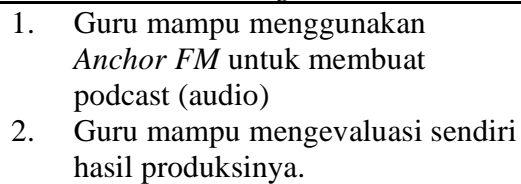 \\
\hline
\end{tabular}

Pada pertemuan kedua hingga pertemuan ketujuh, pelatihan ditekankan pada praktik. Di awal sesi pada pertemuan-pertemuan tersebut, tutor memberikan materi pengenalan kegunaan, bentuk keluaran produk ajar, dan halhal yang perlu disiapkan untuk mendukung praktik produksi bahan ajar. Kemudian, setelah mengenal seluk beluk media pembelajaran digitalnya, para guru mulai melakukan praktik di laptop masing-masing atau di komputer yang ada di ruang laboratorium komputer sekolah dan dipandu oleh tutor.

Pada pertemuan ketujuh atau pertemuan terakhir, tutor dan guru mengadakan evaluasi bersama atas implementasi yang sudah berjalan. Semua produk media pembelajaran digital hasil praktik para guru dikumpulkan di dalam Google Drive atau OneDrive. Kemudian, tutor mengambil sampel dan melakukan evaluasi bersama. Metode evaluasi ini dilakukan melalui wawancara dan FGD. Karena sebagian besar waktu digunakan untuk praktik, guru sudah harus memiliki dan membawa laptop yang memiliki spesifikasi cukup untuk mengoperasikan setiap aplikasi yang digunakan, termasuk smartphone.

\section{HASIL DAN PEMBAHASAN}

Output/luaran yang dihasilkan dari tujuh kali pertemuan pelatihan adalah produk bahan ajar berupa video, audio dan visual, serta modul penggunaan aplikasi untuk proses mengajar bagi guru SMP Budya Wacana Yogyakarta terutama untuk pembelajaran daring secara asinkron. Modul tersebut dibuat dalam bentuk cetak dan digital yang terlihat pada gambar 1 .

\section{A. Pertemuan 1}

Program pelatihan kepada guru SMP Budya Wacana ini diawali dengan focus group discussion (FGD) antara tim pengabdian, kepala sekolah, dan para guru. Topik yang didiskusikan adalah tentang pengenalan perkembangan teknologi komunikasi dan informasi dalam pendidikan, kebutuhan para guru dalam pemanfaatan media pembelajaran berbasis digital, dan beragam aplikasi untuk memproduksi audio dan audiovisual materi pembelajaran. Dalam diskusi, para guru mengungkapkan bahwa dalam kesehariannya sudah cukup terbiasa dengan penggunaan Google Meet dan Zoom untuk menyampaikan materi ajar secara sinkron, tetapi cukup jarang membuat materi ajar dalam bentuk audio dan audiovisual karena belum pernah mendapat pelatihan sebelumnya. Tim pengabdian kemudian menawarkan dan memperkenalkan beragam aplikasi untuk produksi audio dan audiovisual untuk mendukung pembelajaran serta hasil/output-nya dari setiap aplikasi kepada empat belas guru SMP Budya Wacana yang hadir.

Dari diskusi ini dan mempertimbangkan kebutuhan para guru SMP Budya Wacana serta dari beberapa aplikasi produksi materi ajar yang telah ditawarkan, para guru dan kepala sekolah memutuskan untuk memulai pelatihan terkait penggunaan aplikasi: (1) Anchor, (2) PowerPoint recording, (3) Screencast-O-Matic (atau Prezi sebagai tambahan), dan (4) Streamyard (optional/tambahan). Selain penggunaan media, para guru juga membutuhkan pelatihan public speaking dengan penekanan pada aspek audio dan visual serta pembuatan desain layout Power Point.

Gambar 1. Modul Pelatihan Cetak dan Format Digital

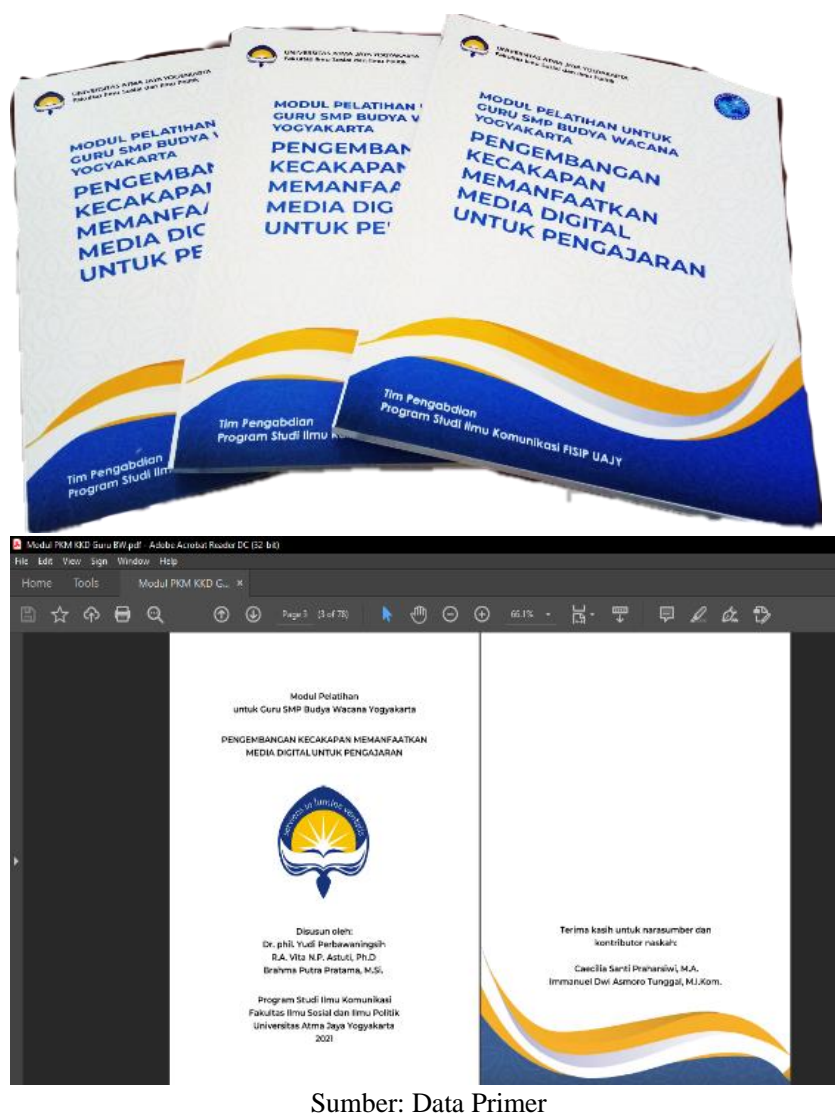

\section{B. Pertemuan 2}

Pertemuan kedua merupakan langkah persiapan untuk pelaksanaan pelatihan bagi para guru. Persiapan ini meliputi persiapan perangkat untuk memproduksi audio dan audiovisual serta pemasangan aplikasi di perangkat/gawai 
para guru dan juga pembuatan akun untuk mengoperasionalkan beberapa aplikasi. Dalam persiapan perangkat, para guru didampingi para tutor memeriksa spesifikasi dan aplikasi pendukung pelatihan yang sudah terpasang di perangkat/gawai masing-masing guru, baik itu dari laptop pribadi atau komputer di laboratorium komputer. Misalnya, spesifikasi dan aplikasi yang dibutuhkan untuk PowerPoint recording adalah perangkat dengan Office 365 atau Office 2016. Selain itu, jika tidak memiliki aplikasi tersebut yang terinstal, para guru bisa menggunakan aplikasi tersebut secara online atau versi website Microsoft Office 365 dengan membuat akun Microsoft terlebih dahulu. Pembuatan akun juga dibutuhkan oleh para guru sebelum menggunakan Anchor. Sedangkan untuk Screencast-OMatic, para guru harus mengunduh dan menginstalnya di perangkat/gawai masing-masing.

\section{Pertemuan 3}

Di pertemuan ketiga, para guru dibekali dan dikenalkan dengan materi dasar berkomunikasi, khususnya terkait teknik pembuatan konten yang baik dan menarik serta teknik berbicara yang baik di depan kamera/audio. Materi pelatihan yang disampaikan oleh Immanuel Dwi Asmoro Tunggal meliputi public speaking di era 4.0 dan masa pandemi, cara berkomunikasi pada audiens melalui media, platform-platform media sosial yang digunakan, kelengkapan produksi audio dan audiovisual, aspek-aspek yang dipertimbangkan ketika berkomunikasi dengan video, tahap-tahap membuat video, cara meningkatkan kualitas berbicara di depan kamera, dan pengaturan letak video dan posisi pembicara ketika digabungkan dengan materi di slide PowerPoint baik menggunakan PowerPoint recording atau Screencast-O-Matic. Para guru pun kemudian mulai mempraktikkan materi menggunakan kamera yang terdapat di perangkat mereka masing-masing, seperti pada gambar 2 .

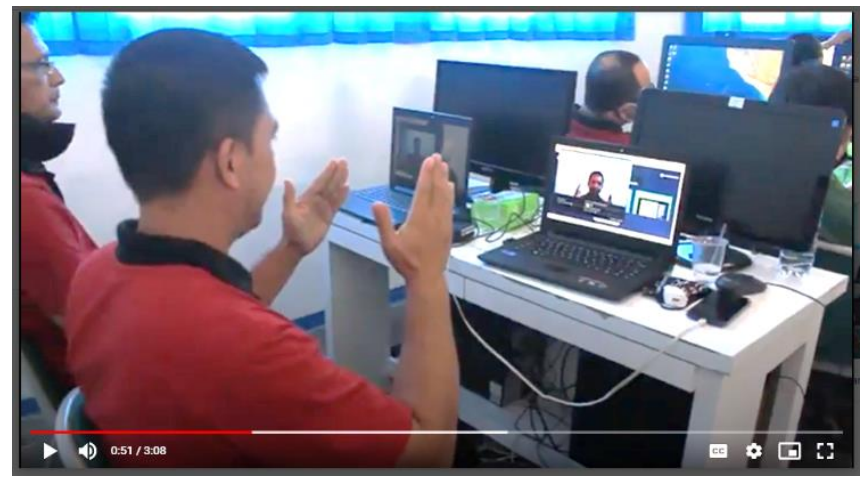

Gambar 2. Tangkapan Layar Praktik Latihan Berbicara yang Baik di Depan Kamera Sumber: Data Primer

\section{Pertemuan 4}

Pertemuan keempat dan kelima merupakan pelatihan produksi materi ajar menggunakan Screencast-OMatic. Tim pengabdian melakukan pelatihan di ruang laboratorium komputer dan diikuti oleh sepuluh guru SMP Budya Wacana. Pelatihan dimulai pukul 10.15 WIB dan materi dibawakan oleh Brahma Putra sebagai narasumber atau tutor utama dan dengan dukungan Yudi Perbawaningsih dan R.A. Vita Astuti. Pada pertemuan keempat, para guru dikenalkan dengan fitur-fitur yang disediakan oleh aplikasi Screencast-O-Matic, cara memproduksi audio dan/atau audivisual, dan keunggulan dari penggunaan dan produk dari aplikasi ini. Dengan Screencast-O-Matic, para guru bisa memproduksi dan memodifikasi video dengan menampilkan materi Power Point saja, wajah pembicara dengan ukuran kecil, wajah pembicara dalam ukuran yang besar. Pada gambar 3, setelah pemaparan materi, para guru mulai praktik mencoba fiturfitur yang disediakan oleh aplikasi tersebut dan para guru sangat antusias melakukannya menggunakan laptop, komputer atau smartphone mereka.

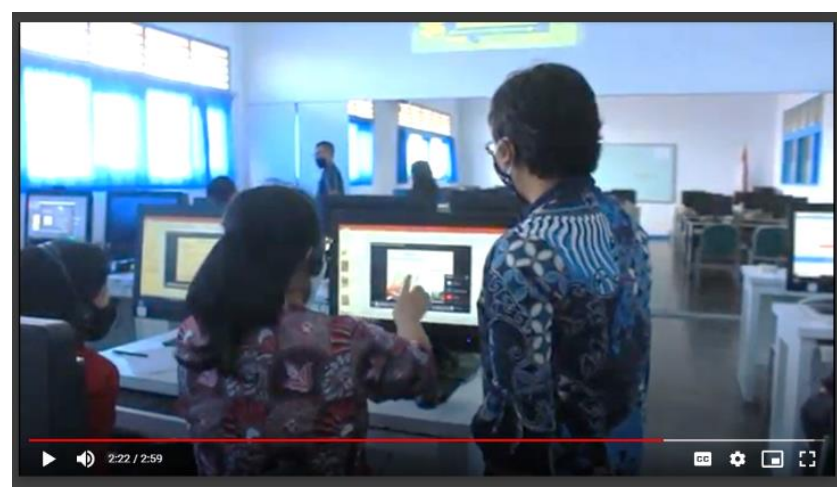

Gambar 3. Tangkapan Layar Praktik Mencoba Fitur-Fitur Aplikasi Screencast-O-Matic Sumber: Data Primer

\section{E. Pertemuan 5}

Di pertemuan kelima, para guru mengembangkan produksi audio atau audiovisualnya dengan menambahkan background sound dan subtitlelcaption di output mereka. Para guru dapat mencoba menambahkan background sound yang sudah disediakan oleh aplikasi atau dari file mp3 atau sound mereka sendiri. Setelah itu, untuk memfasilitasi atau memperjelas pemaparan guru di dalam video, para guru memanfaatkan fitur penambahan caption/subtitle dengan menuliskan verbal mereka di Notepad disertai formula waktunya dan kemudian file tersebut disimpan dalam format .srt. 


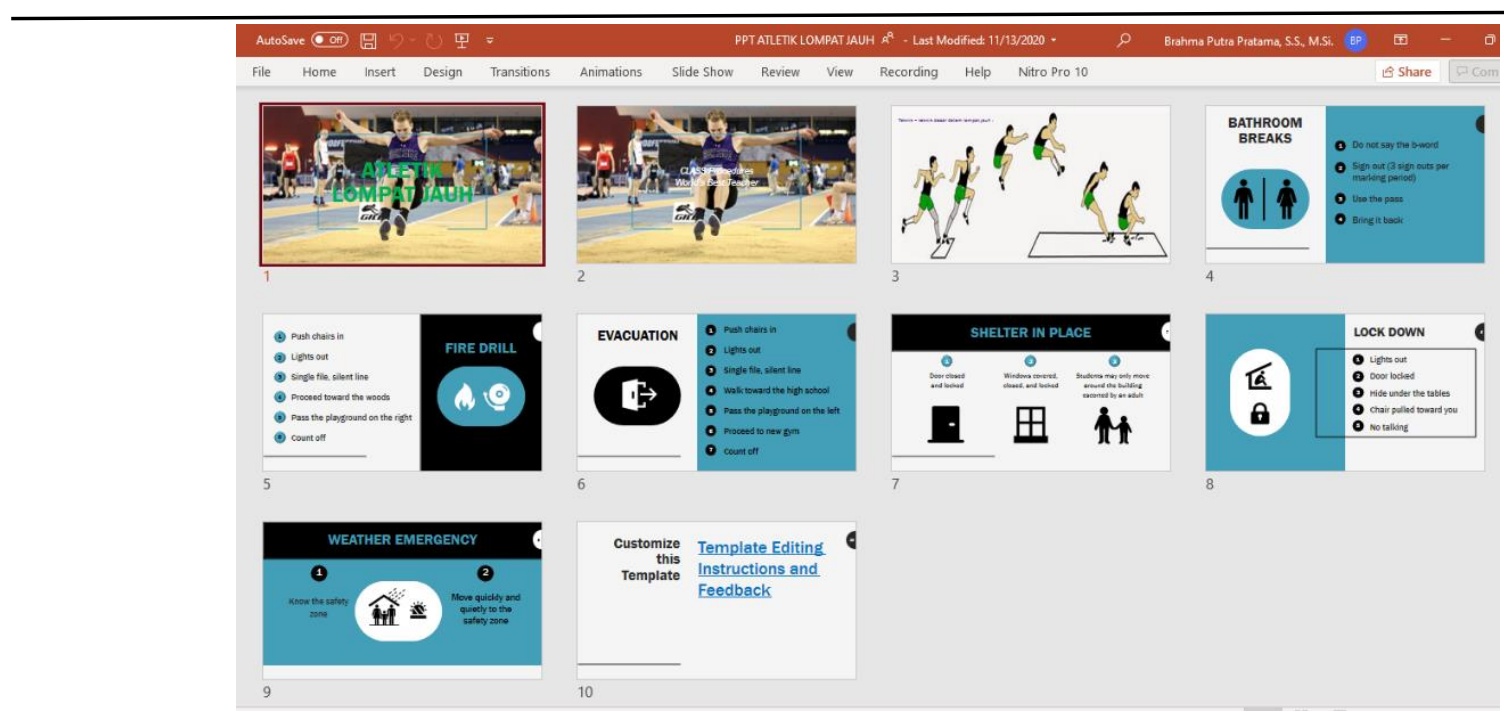

Gambar 4. Tangkapan Layar Produk Visual Slide Power Point tanpa Audio Recording Sumber: Data Primer

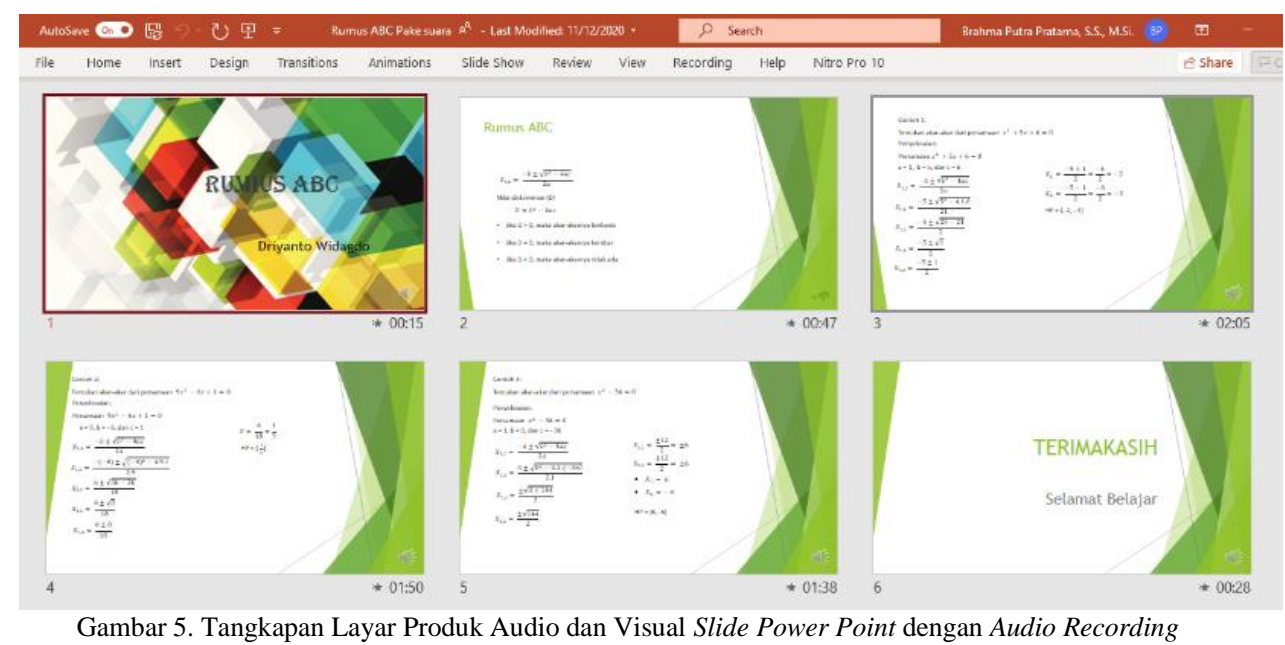
Sumber: Data Primer

\section{F. Pertemuan 6}

Pelatihan dilaksanakan di ruang laboratorium komputer di lantai 2 SMP Budya Wacana dan dimulai pukul 10.30 WIB. Pelatihan ini dihadiri sebelas guru SMP Budya Wacana. Materi pelatihan Power Point recording dibawakan oleh Caecilia Santi sebagai narasumber atau tutor utama dan didukung oleh Brahma Putra sebagai partner. Para guru mempelajari kembali fungsi-fungsi umum menu dalam aplikasi Power Point dan menu untuk recording. Setelah penyampaian materi, para guru mencoba membuat presentasi singkat tanpa audio recording dan salah satu karya dari para guru ditampilkan sehingga dapat memberi contoh kepada guru-guru yang lain. Gambar 4 menunjukkan produk materi ajar mata pelajaran Pendidikan Jasmani, Olahraga, dan Kesehatan.

Pelatihan berjalan dengan lancar karena sebagian besar para guru sudah memiliki office dengan versi minimal 2010 hingga 2016, walaupun tidak ada yang menggunakan office versi 365 . Setelah penyampaian materi, para guru mencoba membuat presentasi singkat dan salah satu karya dari para guru ditampilkan sehingga dapat memberi contoh kepada guru-guru yang lain. Seperti yang terlihat di gambar 5, produk seorang guru berupa materi ajar mata pelajaran matematika yang di setiap slidenya terdapat audio recording penjelasan. Audio recording ini ditandai dengan adanya ikon berbentuk speaker di pojok kanan bawah setiap slide Power Point. Untuk pertemuan selanjutnya, para guru diminta untuk menampilkan karyanya berdasarkan media yang telah dipelajari dan akan dievaluasi tim pengabdian untuk memberikan saran aspek-aspek apa saja yang bisa dikembangkan atau diperbaiki.

\section{G. Pertemuan 7}


Pada pertemuan ketujuh, para guru melanjutkan pelatihan terkait penggunaan Anchor yang dibawakan oleh R.A. Vita Astuti sebagai narasumber utama dan didukung Yudi Perbawaningsih sebagai partner. Perangkat yang digunakan oleh para guru untuk memproduksi podcast melalui Anchor adalah smartphone. Dalam penyampaian materi, para guru tidak hanya belajar menggunakan aplikasi Anchor, tetapi juga berbicara dengan memperhatikan aspek parabahasa, seperti intonansi, tempo, pitch, dll. Para guru memulai pelatihan praktik dengan login ke akun Anchor dan mengklik tombol Record untuk mulai merekam. Selain itu, setelah selesai recording, para guru pun belajar untuk mempublikasikan hasil produksi audionya.

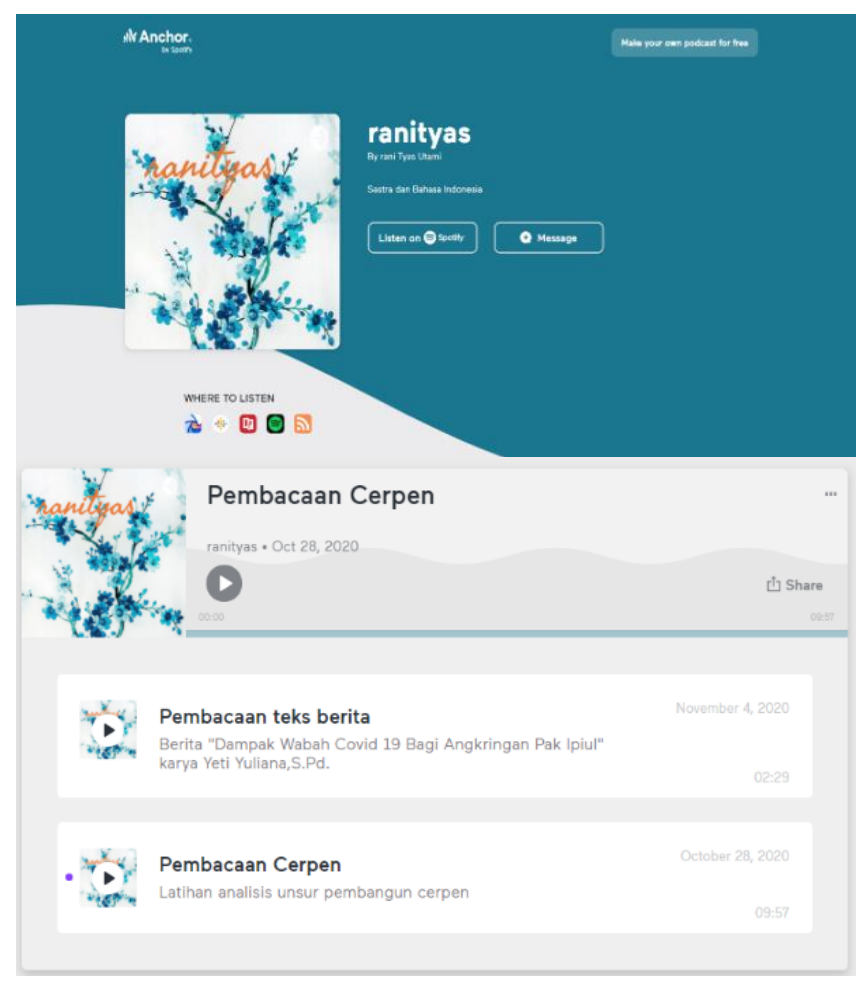

Gambar 6. Tangkapan Layar Produk Audio Pembelajaran Bahasa Indonesia di Anchor

Sumber: https://anchor.fm/rani-tyas-utami

Di akhir pelatihan, tim pengabdian meminta salah satu guru untuk menampilkan hasil uji coba pembuatan videonya terkait mata pelajaran bahasa Jawa yang diampunya. Guru tersebut berhasil membuat produk pembelajaran berupa audiovisual menggunakan aplikasi Screencast-O-Matic dan juga sangat mempertimbangkan pemilihan background sound untuk mendukung materi yang disampaikan.

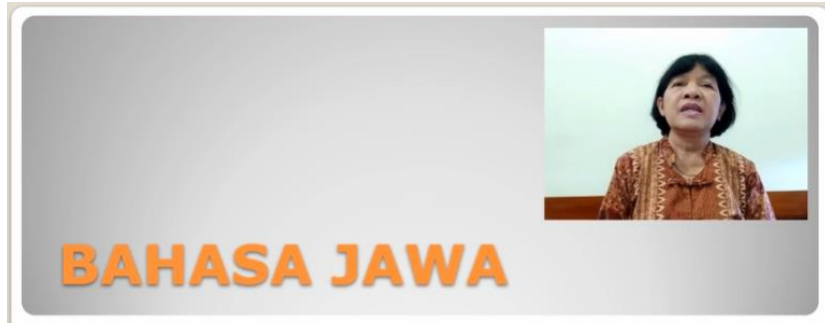

MATERI: UNGGAH-UNGGUH NJALUK PANGAPURA

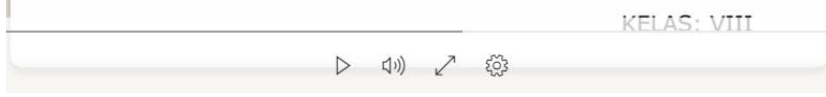

Gambar 7. Tangkapan Layar Produk Video Pembelajaran Bahasa Jawa Menggunakan Screencast-O-Matic Sumber: Data Primer

\section{H. Evaluasi Guru SMP Budya Wacana terkait Program Pengabdian}

Pada akhir pertemuan dengan para guru SMP Budya Wacana, selain ada evaluasi produk bahan ajar dari para tutor, para guru juga memberikan evaluasi terhadap pelaksanaan program pengabdian ini. Melalui form evaluasi yang diberikan kepada para guru, tim pengabdian menanyakan kesan, penilaian, atau harapan dari para guru baik dari program yang telah berjalan maupun program yang selanjutnya ke depan.

Terkait pelatihan PowerPoint recording, para guru mengevaluasi dua hal, yaitu pemateri dan materi yang disampaikan. Kesan yang diungkapkan oleh para guru terkait narasumber adalah penguasaan materi narasumber yang baik, sedangkan terkait materi yang disampaikan adalah materi PowerPoint recording ini sangat membantu, menarik, dan menyenangkan, serta mudah diaplikasikan. Para guru merasa bahwa materi ini memang dibutuhkan sebagai media pembelajaran.

Terkait pelatihan Anchor (podcast), para guru memberikan evaluasi terkait materi yang disampaikan. Menurut mereka, materi ini sangat membantu dan membuat penyampaian materi menjadi menarik. Selain itu, materi juga bermanfaat bagi para guru.

Terkait pelatihan Screencast-O-Matic, para memberikan kesan bahwa materi ini sangat membantu, memberikan semangat, menarik, dan mudah digunakan atau diaplikasikan. Sementara itu terkait pemateri, para guru menilai bahwa penyampaian materi sangat jelas dan sistematis.

Terkait pelatihan berbicara dan menulis di media digital, para guru memberikan penilaian terhadap pemateri dan materi yang disampaikan. Para guru merasa bahwa pemateri menguasai materi dengan baik dan sangat bagus serta jelas dalam menjelaskan. Akan tetapi, terkait waktu pelatihan dirasa masih kurang, sehingga ada hal yang belum 
dipraktikkan. Dari sisi materi, para guru merasa materi ini penting, sangat bermanfaat, sangat diperlukan, mudah dipahami karena adanya contoh praktik langsung. Para guru berharap materi ini bisa menambah pengetahuan dan teknik dalam penyampaian materi.

\section{KESIMPULAN}

Program pengabdian kepada masyarakat berupa pelatihan penggunaan aplikasi untuk memproduksi bahan ajar bagi guru SMP Budya Wacana Yogyakarta diadakan sebagai upaya Sekolah Budya Wacana melalui YPPN meningkatkan kualitas sekolah dan memberikan positioning di antara sekolah-sekolah swasta lainnya dengan melakukan perombakan kurikulum. Kurikulum ini disesuaikan dengan perubahan-perubahan sosial di era industri 4.0. YPPN berkomitmen untuk membentuk dan membekali para siswa yang bersekolah di Budya Wacana, khususnya SMP Budya Wacana untuk memiliki kecapakan dalam komunikasi digital dan karakter yang bermartabat. Selain itu, untuk mewujudkannya, YPPN membutuhkan bantuan sumber daya manusia yang memiliki kompetensi dan pengetahuan dalam menyusun dan mengembangkan modul dan model pembelajaran komunikasi digital. Oleh karena itu, program pengabdian ini juga ditujukan untuk meningkatkan kualitas pengetahuan dan skills para guru pengajar/pendamping.

Solusi atas pemasalahan SMP Budya Wacana yang diberikan oleh tim pengabdian adalah dengan memberikan pelatihan pemanfaatan teknologi dan media digital kepada para guru, terutama untuk mendukung dan membantu proses belajar mengajar. Perkembangan teknologi informasi dan komunikasi serta media baru dapat dimanfaatkan oleh para guru untuk membuat produksi bahan ajar dalam bentuk audio maupun audiovisual sehingga bahan ajar tersebut dapat digunakan dalam pembelajaran yang sifatnya asyncronous, atau menggunakan aplikasi video conference untuk kepentingan pembelajaran interaktif tatap muka (syncronous).

Proses pengembangan kecapakan komunikasi digital bagi guru SMP Budya Wacana ini dilakukan dalam tujuh kali pertemuan yang direntang dalam durasi dua bulan. Proses ini merupakan bagian dari proses pengembangan kemampuan digital kepada guru dan siswa SMP dalam mata pelajaran Kecakapan Komunikasi Digital, yang dirancang dalam empat semester atau dua tahun. Output dari pelatihan ini adalah bahan ajar para guru SMP berupa video, audio dan visual, serta modul penggunaan aplikasi. Diharapkan melalui pelatihan ini para guru semakin berdaya dalam menggunakan teknologi informasi dan komunikasi untuk mendukung kegiatan belajar mengajar, khususnya dalam masa pandemi Covid-19.

\section{DAFTAR PUSTAKA}

[1] Y. Debora, "Riwayat kasus corona di Indonesia, dari Maret hingga September 2020," Tirto.id, para. 8, 11
Sept 2020. [Online], Tersedia di: https://tirto.id/riwayatkasus-corona-di-indonesia-dari-maret-hinggaseptember-2020-f4d6. [Diakses 1 Sept 2021].

[2] Kementerian Pendidikan dan Kebudayaan Republik Indonesia, "Surat Edaran Menteri Pendidikan dan Kebudayaan Republik Indonesia No. 4 Tahun 2020 tentang Pelaksanaan Kebijakan Pendidikan Dalam Masa Darurat Penyebaran Coronavirus Disease (Covid-19)", 24 Maret 2020, Tersedia: https://www.kemdikbud.go.id/main/blog/2020/03/semendikbud-pelaksanaan-kebijakan-pendidikan-dalammasa-darurat-penyebaran-covid19 [Diakses: 11 September 2021]

[3] O. McGarr dan A. McDonagh, "Exploring the digital competence of pre-service teachers on entry onto an initial teacher education programme in Ireland," Irish

Educational Studies, vol. 40, no. 1, pp. 115-128, 2020.

[4] R. J. Krumsvik, "Digital competence in the Norwegian teacher education and schools," Högre utbildning, 2011. [Online], Tersedia di:

https://hogreutbildning.se/index.php/hu/article/view/874.

[Diakses 1 September 2021]

[5] T. H. Nurgiansah dan Sukmawati, "Tantangan guru Pendidikan Kewarganegaraan di masa adaptasi kebiasaan baru," Jurnal Pendidikan Ilmu Sosial, vol. 17, no. 2, pp. 139-149, 2020.

[6] N. Sari, "Problematika pelaksanaan pembelajaran daring masa pandemic Covid-19 di MIN 3 Medan," Journal of Education and Teaching Learning, vol. 2, no. 3, pp 4457, 2020.

[7] E. Instefjord, “Appropriation digital competence in teacher education," Nordic Journal of Digital Literacy, vol. 9, no 4, pp. 313-329, 2014.

[8] R. D. Prayogi dan R. Estetika, "Kecakapan Abad 21: Kompetensi Digital Pendidik Masa Depan," Jurnal Manajemen Pendidikan, vol. 14, no. 2, pp. 144-151, 2019.

[9] Y. Perbawaningsih, "Plus Minus of ICT Usage in Higher Education Students," Procedia - Social and Behavioral Sciences, vol. 103, pp. 717-724, 2013.

[10] E. Surahman, R. Santaria, dan E. I. Setiawan, "Tantangan pembelajaran daring di Indonesia," Journal of Islamic Education Management, vol. 5, no. 2, pp. 8998, 2020.

[11] H. J. Pentury, I. B. Rangka, dan A. D. Anggraeni, "Peningkatan kemampuan pedagogik guru dalam pembelajaran daring melalui penerapan kuis interaktif daring," Jurnal Surya Masyarakat, vol. 3, no. 2, pp. 109114, 2021.

[12] Yayasan Pendidikan dan Pengajaran Nasional Budya Wacana Yogyakarta, "Sejarah YPPN Budya Wacana", 2016. Tersedia: https://budyawacana.sch.id/profil-7. [Diakses 1 September 2021] 